\title{
MORPHOLOGICAL, PHYSIOLOGICAL, AND CHEMOTAXONOMICAL CHARACTERISTICS OF IRON- AND SULFUR-OXIDIZING BACTERIA ISOLATED FROM ACID MINE DRAINAGE WATERS
}

\author{
NORIO WAKAO,* KAZUO HANADA, ATSUSHI TAKAHASHI, \\ YONEKICHI SAKURAI, AND HIDEO SHIOTA \\ Laboratory of Applied Microbiology, Department of Agricultural Chemistry, \\ Faculty of Agriculture, Iwate University, Morioka 020, Japan
}

(Received August 10, 1990)

\begin{abstract}
Two strains, $\mathrm{Fe} 1$ and $\mathrm{Fe} 2$, of iron-oxidizing bacteria from acid drainage water at the Matsuo mine showed dissimilar characteristics of red-brown colonies on $\mathrm{FeSO}_{4}-9 \mathrm{~K}$ silica gel plates. The $\mathrm{Fel}$ colonies were large and irregular. The $\mathrm{Fe} 2$ colonies were minute and circular. These bacteria, identified as Thiobacillus ferrooxidans on the basis of their physiological and chemotaxonomical properties (fatty acid composition, ubiquinone type, and DNA base composition), were different strains. Fe2 differed from $\mathrm{Fel}$ in its extremely low oxidizing activity of sulfur and thiosulfate. Two strains, $\mathbf{S} 2$ and $\mathbf{S} 3$, of sulfur-oxidizing bacteria were separately isolated on $\mathrm{Na}_{2} \mathrm{~S}_{2} \mathrm{O}_{3}-9 \mathrm{~K}$ silica gel plates and agar plates, respectively. However, $\mathrm{S} 2$ and $\mathrm{S} 3$ formed pale brown and pale yellow colonies on the silica gel and agar plates, respectively. Since these two strains were identical in their properties, they were judged to be quite similar or the same strain. From their morphological, physiological, and chemotaxonomical properties, they were identified as Thiobacillus thiooxidans. The oxidation characteristics of both sulfur and thiosulfate by the strains of iron- and sulfur-oxidizing bacteria were also investigated.
\end{abstract}

The sulfur-oxidizing bacterium Thiobacillus thiooxidans was first isolated in 1921 from soil(28). Twenty-six years later Colmer and Hinkle reported the first isolation of Thiobacillus ferrooxidans responsible for the oxidation of iron and inorganic sulfur compounds from the acid mine drainage of bituminous coal mines (1). Since then, the iron- and sulfur-oxidizing Thiobacillus species were shown to occur widely in nature especially where oxidisable sulfur and iron are

* Address reprint requests to: Dr. N. Wakao, Department of Agricultural Chemistry, Faculty of Agriculture, Iwate University, Morioka 020, Japan. 
abundant (11). T. ferrooxidans and $T$. thiooxidans have continued to draw much interest because of their unique physiological characters (e.g. autotrophilism and acidophilism), environmental impact (e.g. acid and metal pollution), and commercial value (e.g. metal recovery by bacterial leaching and desulfurization of coal).

However, current knowledge of $T$. ferrooxidans and $T$. thiooxidans is based on a study of relatively few strains, as they are rather difficult to produce in pure culture and are troublesome to maintain. Extensive and systematic collections of these species from diverse localities and habitats in the world are very important for better understanding their genetic, physiological, and taxonomical properties (8).

We studied the ecological aspects of acidophilic chemolithotrophic iron- and sulfur-oxidizing bacteria at the abandoned Matsuo sulfur and iron sulfide (pyrite) mine areas $(21,22,24)$ and the leaching of pyrite ores by the bacteria $(25-27)$. We found that iron- and sulfur-oxidizing bacteria were ubiquitously distributed in both acid mine waters and pyrite ores, and were responsible for the rapid oxidation of iron and sulfur and the degradation of the ores.

However, no detailed information has been obtained about the biology of the bacteria living in the mine areas. In this investigation we isolated and characterized the iron- and sulfur-oxidizing bacteria ( $T$. ferrooxidans and $T$. thiooxidans) from the mine areas. The presence of different strains of iron-oxidizing bacteria is reported.

\section{MATERIALS AND METHODS}

Study area and sampling. The abandoned Matsuo sulfur and iron sulfide mine is on the Hachimantai volcano in Iwate Prefecture. Many small creeks and a large stream of acid mine water are discharged from the mine area and pour directly into the River Akagawa, meaning red river. Properties of the acid mine waters and the acid-polluted river water and sampling stations were shown in previous reports $(22,24)$. Water samples were collected in sterilized $0.5-l$ Ehrlenmyer flasks and brought to the laboratory for analyses within $5 \mathrm{~h}$ after sampling. The sampling period was from 1976 until 1980.

Bacteria. Thiobacillus ferrooxidans NCIB 8455 was used as a type strain of iron-oxidizing bacteria.

Media. Distilled water was used to prepare all media. The $\mathrm{pH}$ of the media was adjusted by adding $\mathrm{H}_{2} \mathrm{SO}_{4}$ or $\mathrm{NaOH}$. Liquid and solid cultures were incubated at 30 and $25^{\circ} \mathrm{C}$, respectively, unless otherwise noted. The basal salts medium of $9 \mathrm{~K}$ reported by Silverman and Lundgren (18) was used throughout this study. It was composed of $3.0 \mathrm{~g}\left(\mathrm{NH}_{4}\right)_{2} \mathrm{SO}_{4}, 0.1 \mathrm{~g} \mathrm{KCl}, 0.5 \mathrm{~g} \mathrm{~K}_{2} \mathrm{HPO}_{4}, 0.5 \mathrm{~g} \mathrm{MgSO}_{4} \cdot 7 \mathrm{H}_{2} \mathrm{O}$,

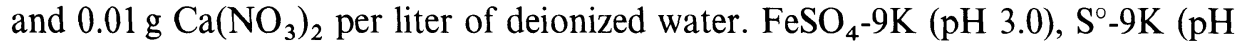
3.0), and $\mathrm{Na}_{2} \mathrm{~S}_{2} \mathrm{O}_{3}-9 \mathrm{~K}$ ( $\mathrm{pH} 5.0$ ) media were prepared by supplementing the basal salts medium with $2 \%(\mathrm{w} / \mathrm{v}) \mathrm{FeSO}_{4} \cdot 7 \mathrm{H}_{2} \mathrm{O}, 2 \%(\mathrm{w} / \mathrm{v})$ elemental sulfur, and $1 \%$ (w/v) $\mathrm{Na}_{2} \mathrm{~S}_{2} \mathrm{O}_{3} \cdot 5 \mathrm{H}_{2} \mathrm{O}$, respectively. $\mathrm{FeSO}_{4}$ and $\mathrm{Na}_{2} \mathrm{~S}_{2} \mathrm{O}_{3}$ solutions were prepared separately and sterilized by filtration through a $0.2 \mu \mathrm{m}$ membrane filter (Toyo 
Roshi Co.). Powdered elemental sulfur was sterilized by autoclaving at $120^{\circ} \mathrm{C}$ for 30 min. FeSO $_{4}-9 \mathrm{~K}$ silica gel and $\mathrm{Na}_{2} \mathrm{~S}_{2} \mathrm{O}_{3}-9 \mathrm{~K}$ agar (Difco Bacto agar, Difco Laboratories, Detroit) plates were prepared according to the procedures described previously $(21,23)$. The same procedures were also used to prepare $\mathrm{Na}_{2} \mathrm{~S}_{2} \mathrm{O}_{3}-9 \mathrm{~K}$ silica gel plates. Nutrient broth was composed of $10 \mathrm{~g}$ polypeptone, $10 \mathrm{~g}$ meat extract, and $5 \mathrm{~g} \mathrm{NaCl}$ per liter of deionized water, and adjusted to $\mathrm{pH} 3$.

Cultivation. A 50-ml liquid medium prepared in a 500-ml flat-bottom culture flask was used in this study, unless otherwise noted. One ml of cell suspension was usually inoculated into the $50 \mathrm{ml}$ liquid medium. Shaking cultures were carried out on a reciprocal shaker operating at $120 \mathrm{rpm}$. A large-scale culture of iron-oxidizing bacteria was made using $3 l$ of $\mathrm{FeSO}_{4}-9 \mathrm{~K}$ medium in a $3-l$ flat-bottom flask under forced aeration at $25^{\circ} \mathrm{C}$ for 3-4 days. For mass culture of sulfur-oxidizing bacteria, many $500-\mathrm{ml}$ flat-bottom flasks containing $100 \mathrm{ml}$ of $\mathrm{S}^{\circ}-9 \mathrm{~K}$ liquid medium in each were shaken for a week. For plating out, $0.1 \mathrm{ml}$ of cell suspension or water sample was spread on a silica gel or agar plate with a bent glass rod. The inoculated plates were incubated in a sealed polyvinyl-bag to keep the medium from drying.

Oxygen requirement was examined by cultivating the bacteria in GasPak Anaerobic Systems (BBL, Cockeysville, Md.). The effect of temperature on growth was examined in the range of 3 to $50^{\circ} \mathrm{C}$ using a Temperature Gradient Incubator TN-3 (Toyo Scientific Co.). The effect of $\mathrm{pH}$ on growth and activity (utilization of substrates as an energy source) was examined in the range of $\mathrm{pH}$ from 1 to 7 . Glucose utilization was verified according to the method of Shafia and Wilkinson (17), in which $9 \mathrm{~K}$ salts medium $(\mathrm{pH} 3.0)$ supplemented with glucose $(1 \%)$ and yeast extract $(0.01 \%)$ was used. Utilization of $\left(\mathrm{NH}_{4}\right)_{2} \mathrm{SO}_{4}, \mathrm{NH}_{4} \mathrm{Cl}$, and $\mathrm{KNO}_{3}$ as an inorganic nitrogen source $(640 \mathrm{mg} \mathrm{N} / l)$ was examined using nitrogen-free $\mathrm{FeSO}_{4}-9 \mathrm{~K}$ and $\mathrm{S}^{\circ}-9 \mathrm{~K}$ media. Utilization of organic nitrogen compounds $(0.1 \mathrm{~g} / l)$, such as, peptone, yeast extract, and glutamic acid, was also examined as nitrogen sources.

Cell harvest. After liquid cultivation of iron- or sulfur-oxidizing bacteria, followed by centrifugation at $1,500 \times g$ for $10 \mathrm{~min}$ to remove iron precipitates or residual sulfur particles, the bacterial cells in the supernatants were harvested by centrifuging at $12,000 \times g$ for $10 \mathrm{~min}$. The resulting cell pellet was washed three times with sterilized acid water $(\mathrm{pH} 1.5)$ and then twice with sterilized water, and finally resuspended in a small volume of sterilized water to give the original cell suspensions used as inocula.

Cell count. Total bacterial numbers were counted with a bacterial counting chamber (Erma Optics Co., Tokyo) under a phase-contrast microscope. Viable numbers were estimated by spreading appropriate dilutions on the solid medium.

Analyses. Sulfate and soluble iron (total and ferrous) were determined by the barium sulfate turbidity (4) and $\alpha, \alpha^{\prime}$-dipyridyl (6) methods, respectively. The amounts of sulfate and iron were calculated in $\mathrm{mg} / \mathrm{l}$. The degree of iron oxidation was expressed as the ratio of ferric to total iron $\left(\mathrm{Fe}^{3+} / \Sigma \mathrm{Fe} ; \%\right)$. Thiosulfate and glucose were determined by the iodometric titration(19) and phenol-sulfate (5) 
methods, respectively, and were calculated in $\mathrm{mg} / \mathrm{ml}$. $\mathrm{pH}$ was measured with a glass electrode $\mathrm{pH}$ meter.

Light microscopy. The sizes and shapes of the bacterial cells stained with a dilute Ziehl carbolic fuchsin were observed under a light microscope. Gram staining was carried out by a modification of Hucker's method (7).

Electron microscopy. The bacterial cells in liquid cultures were harvested and washed according to the procedures described above. The cell pellets were resuspended and fixed in $2 \%(\mathrm{v} / \mathrm{v})$ glutaraldehyde in $0.1 \mathrm{~m}$ phosphate buffer $(\mathrm{pH}$ 7.2) for more than $2 \mathrm{~h}$ at $4^{\circ} \mathrm{C}$. The fixed cells were mounted on copper grids, evaporated with $\mathrm{Cr}$, and examined with a Hitachi model HU-125E transmission electron microscope.

DNA base composition. DNA was prepared from the cells of late exponential liquid cultures according to the method of Marmur(12). The $\mathrm{G}+\mathrm{C}$ content of DNA (mol\%) was obtained by the melting temperature $\left(T_{\mathrm{m}}\right)$ method of Marmur and Doty (13) as modified by De Ley (3), using a Beckman DU-8 spectrophotometer (Beckman-Japan Co., Tokyo). The DNA of Escherichia coli $\mathrm{K} 12$ was used as a reference.

Quinone system. Cells were collected during the early stationary growth and freeze-dried. Quinones were extracted from the lyophilized cells and purified by thin-layer chromatography using a silica-gel plate (GF 254; E. Merck) as described by Katayama-Fujimura et al.(10). The purified ubiquinone system was analyzed by a Shimadzu High-Performance Liquid Chromatograph LC-3A (Shimadzu Seisakusho Ltd., Kyoto) fitted with a Dupont Zorbax-ODS column (4.6 mm $\times 250$ $\mathrm{mm})$ and methanol-iso-propylether $(3: 1, \mathrm{v} / \mathrm{v})(1 \mathrm{ml} / \mathrm{min})$ as the mobile phase. The quinones were monitored at $275 \mathrm{~nm}$ and quantified using a Shimadzu Chromatopac CR-3A.

Cellular fatty acid composition. Cells were harvested during an early stationary growth, and lyophilized. Fatty acids of the lyophilized cells were methylated and extracted by the method of Miyagawa et al.(14). Fatty acid methyl esters were analyzed using a Shimadzu gas-liquid chromatograph (GLC) GC-8APF with a chromatograph-data processor C-R6A. The GLC apparatus was equipped with a fused silica capillary column $(0.25 \mathrm{~mm} \times 30 \mathrm{~m})$ with SPB-1 (Supelco Japan Ltd., Tokyo). Fatty acids were identified by comparing the retention time of their methyl esters with those of authentic standard fatty acid methyl esters (Supelco Bacterial Acid Methyl Esters CP-Mix). Hydrogenation was used to identify unsaturated and cyclopropane fatty acids. The fatty acids were identified by a Hitachi GC-MS system M 2000 equipped with a HP-5 capillary column $(0.35 \mathrm{~mm} \times 25 \mathrm{~m})$ coated with methyl-silicone (Hewlett Packard Co., Calif.)

\section{RESULTS}

\section{Colony appearances and isolation}

Appropriate dilutions of acid mine waters ( $\mathrm{pH} 1.5-1.7, \mathrm{Fe}^{2+} 1,000 \mathrm{mg} / \mathrm{l}$ ) 


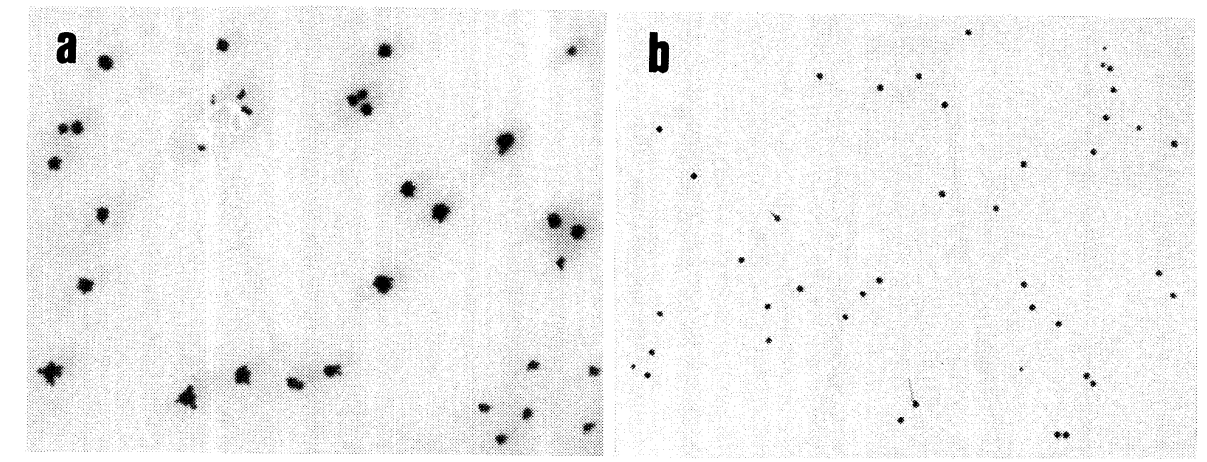

Fig. 1. Colonial appearance of iron-oxidizing bacteria strains Fe1 (a) and Fe2 (b) growing on $\mathrm{FeSO}_{4}-9 \mathrm{~K}$ silica gel plates.

discharged from the mine drift were applied to plating out on $\mathrm{Na}_{2} \mathrm{~S}_{2} \mathrm{O}_{3}-9 \mathrm{~K}$ silica gel and agar media, and on $\mathrm{FeSO}_{4}-9 \mathrm{~K}$ silica gel medium. After 3 weeks of incubation, colonies developed on the plates were observed and isolated.

Red-brown colonies of iron-oxidizing bacteria grown on $\mathrm{FeSO}_{4}$-silica gel plates were divided into two types depending upon colony appearances. One type (Fel) was relatively large and irregular, and the other $(\mathrm{Fe} 2)$ was minute and circular. Each type of the colony was cultivated in $\mathrm{FeSO}_{4}-9 \mathrm{~K}$ liquid medium for a week. After the media became red-brown, the cultures were again inoculated on $\mathrm{FeSO}_{4}-9 \mathrm{~K}$ silica gel plates. Such ordinary purification procedures were repeated several times, and finally pure cultures of the two types were obtained. Colonies of strain $\mathrm{Fe} 1$ (Fig. 1a) were large (1-4 mm) and irregular (auriculate with unequal projections). Colonies of strain Fe2 (Fig. 1b) were very minute $(0.2-0.7 \mathrm{~mm})$, circular, and entire. Colonies of $\mathrm{Fe} 2$ were morphologically similar to those of the type strain $T$. ferrooxidans NCIB 8455

Three types of colonies (S1, S2, and S3) were observed on $\mathrm{Na}_{2} \mathrm{~S}_{2} \mathrm{O}_{3}-9 \mathrm{~K}$ solid medium: creamy white (S1) and pale brown (S2) colonies on the silica gel medium, and pale yellow (S3) on the agar medium. The creamy white colonies (S1) on the silica gel medium were circular, entire, convex or pulvinate, smooth, glistening, and $0.5-2 \mathrm{~mm}$ in diameter. Pale brown colonies (S2) were circular, entire or undulate, convex, smooth, glistening, and $2-4 \mathrm{~mm}$ in diameter. Pale yellow colonies (S3) on the agar medium were circular, entire, convex, smooth, and $2-3 \mathrm{~mm}$ in diameter. Each of colonies $\mathrm{S} 1, \mathrm{~S} 2$, and $\mathrm{S} 3$ was inoculated and cultivated in both $\mathrm{Na}_{2} \mathrm{~S}_{2} \mathrm{O}_{3}$ - and $\mathrm{S}^{\circ}-9 \mathrm{~K}$ media. The $\mathrm{S} 2$ and $\mathrm{S} 3$ colonies grew vigorously in these liquid media. On the other hand, the strain S2 formed pale yellow colonies on the agar plates. In parallel experiments, strain S3 formed pale brown colonies on silica gel plates. Apparently the difference of colony morphology between strains S2 and S3 resulted from the kinds of the solidifying agents used. However, $\mathrm{S} 1$ colonies failed to grow in either $\mathrm{Na}_{2} \mathrm{~S}_{2} \mathrm{O}_{3}-9 \mathrm{~K}$ and $\mathrm{S}^{\circ}-9 \mathrm{~K}$ media or $\mathrm{FeSO}_{4}-9 \mathrm{~K}$ medium. 

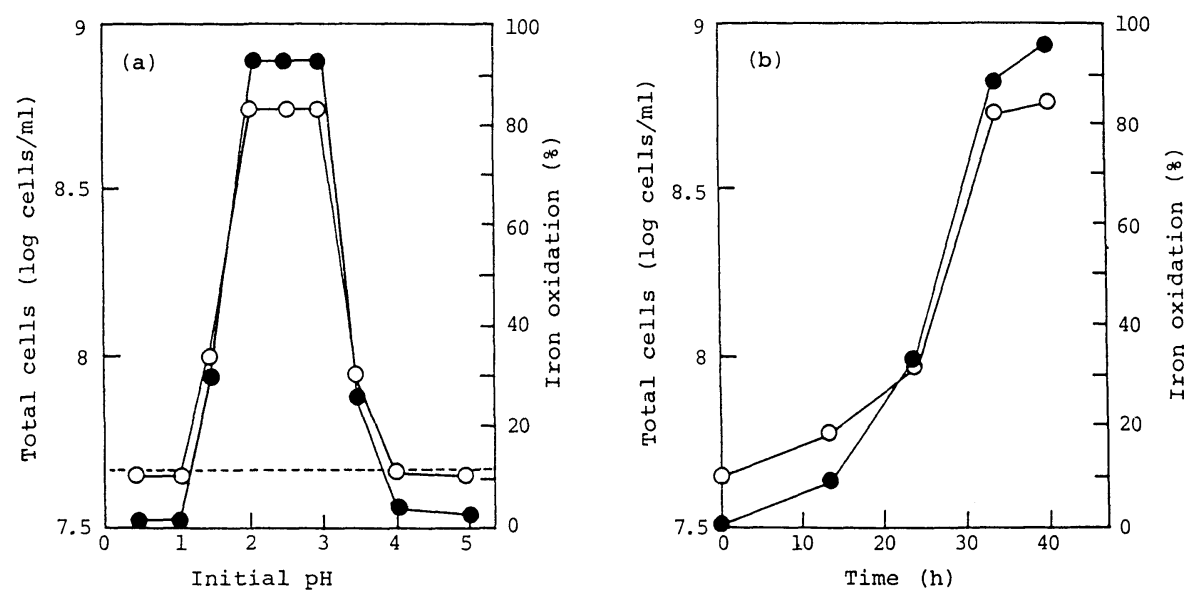

Fig. 2. Effects of $\mathrm{pH}$ on the growth of iron-oxidizing bacteria $(\mathrm{Fel})$ and the oxidation of iron, and the progressive changes in its growth and iron oxidation.

(a): $\mathrm{FeSO}_{4}-9 \mathrm{~K}$ media adjusted to $\mathrm{pH} 0.5-5$ were used and cultivated for $41 \mathrm{~h}$. (b):

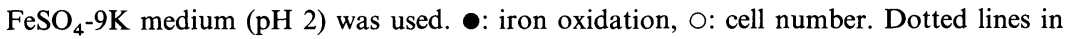
this and subsequent figures indicate the initial cell numbers added.

\section{Cell morphology and some properties}

Cells of S1 colonies in electron microscopic preparations were single, polar flagellated, and rod-shaped. The creamy white $\mathrm{S} 1$ colonies were easily dissolved in $\mathrm{CS}_{2}$, indicating the formation of elemental sulfur crystals outside the cells from thiosulfate.

Strains of sulfur-oxidizing bacteria (S2 and S3) were gram negative, strictly aerobic, single polar flagellated, and rod shaped $(0.4-0.7 \times 0.9-2.2 \mu \mathrm{m})$. Strains of iron-oxidizing bacteria ( $\mathrm{Fe} 1$ and $\mathrm{Fe} 2)$ were also gram negative, strictly aerobic, and rod shaped $(0.4-0.8 \times 0.8-2.3 \mu \mathrm{m})$. Temperatures for growth and sulfur oxidation of strains $\mathrm{S} 2$ and $\mathrm{S} 3$ were in the range of $5-37^{\circ} \mathrm{C}$ (optimum temperature: $25-33^{\circ} \mathrm{C}$ ). No growth and sulfur oxidation occurred at about $5^{\circ} \mathrm{C}$ and above $40^{\circ} \mathrm{C}$. Temperatures for growth and iron oxidation of $\mathrm{Fe} 1$ and $\mathrm{Fe} 2$ were in the range of 5-43 ${ }^{\circ} \mathrm{C}$ (optimum temperature: $25-35^{\circ} \mathrm{C}$ ). Growth and iron oxidation occurred even at about $5^{\circ} \mathrm{C}$ but not above about $45^{\circ} \mathrm{C}$. Ammonium-nitrogen was the most suitable source of nitrogen for all of the strains. Nitrate-nitrogen, peptone, yeast extract, and glutamic acid scarcely affected their growth and oxidation of the substrates. No growth of all the strains occurred in nutrient broth at acid conditions.

\section{Oxidation of iron}

The effect of $\mathrm{pH}$ on the growth and iron oxidation was studied in three strains of iron-oxidizing bacteria ( $\mathrm{Fe} 1, \mathrm{Fe} 2$, and $T$. ferrooxidans NCIB 8455). As shown in the representative results (Fig. 2a), both growth and iron oxidation of all strains occurred at narrow $\mathrm{pH}$ ranges $(\mathrm{pH} 1-4)$. Their optimum $\mathrm{pH}$ was $2-3$. The progressive 

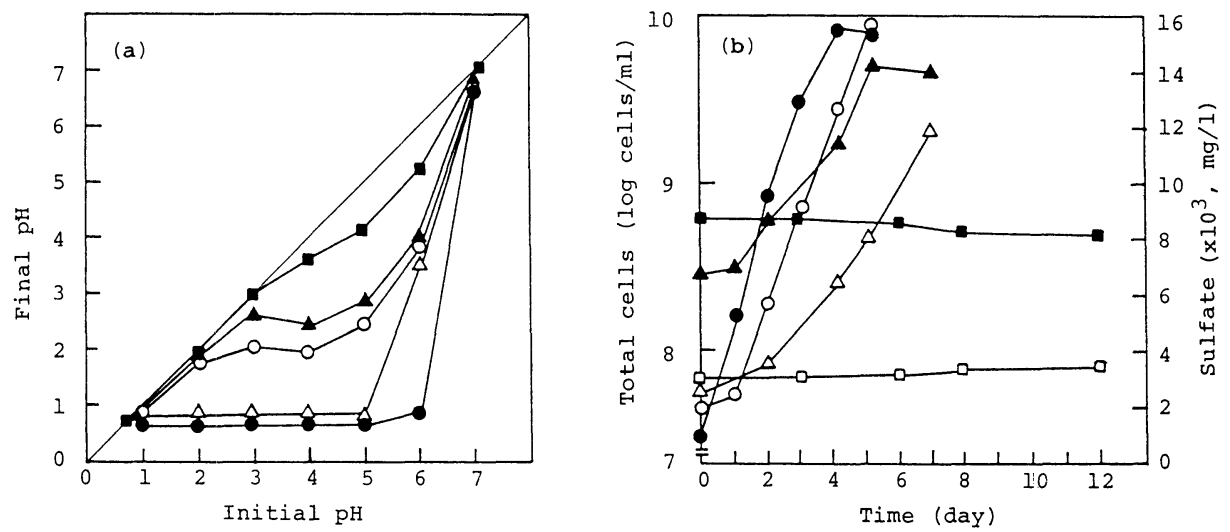

Fig. 3. Effects of $\mathrm{pH}$ on sulfur oxidation by iron- and sulfur-oxidizing bacteria ( $\mathrm{Fe} 1, \mathrm{Fe} 2$, and $\mathrm{S} 2$ ) and progressive changes in their growth and oxidation of the substrate.

(a): $\mathrm{S}^{\circ}-9 \mathrm{~K}$ media adjusted to $\mathrm{pH} \mathrm{1-7}$ were used. Inoculum size: $1.6 \times 10^{8} / \mathrm{ml}(\mathrm{S} 2)(\mathrm{O}$, 1-day culture; •, 3-day culture); $2 \times 10^{8} / \mathrm{ml}(\mathrm{Fel})\left(\boldsymbol{\Lambda}, 7\right.$-day culture); $2 \times 10^{9} / \mathrm{ml}(\mathrm{Fel})(\triangle$, 7-day culture); $4 \times 10^{9} / \mathrm{ml}$ (Fe2) ( $\mathbf{\square}, 7$-day culture). (b): $\mathrm{S}^{\circ}-9 \mathrm{~K}$ medium (pH 5) was used. Inoculum size: $8 \times 10^{7} / \mathrm{ml}(\mathrm{S} 2)(\bullet, \bigcirc) ; 2 \times 10^{9} / \mathrm{ml}(\mathrm{Fe} 1)(\boldsymbol{\Delta}, \triangle) ; 4 \times 10^{9} / \mathrm{ml}(\mathrm{Fe} 2)(\boldsymbol{\square}, \square)$. Closed and open symbols indicate cell number and sulfate, respectively.

changes in their iron oxidation and growth were almost parallel until iron was completely oxidized (Fig. 2b). The specific growth rate $(\mu)\left(\mathrm{h}^{-1}\right)$ and specific iron oxidation rate $\left(\mathrm{h}^{-1}\right)$ were 0.07 and $0.11(\mathrm{Fe} 1), 0.05$ and $0.10(\mathrm{Fe} 2)$, and 0.06 and 0.10 ( $T$. ferrooxidans NCIB 8455).

\section{Oxidation of sulfur}

Figure 3 shows representative results of the growth of iron- and sulfur-oxidizing bacteria ( $\mathrm{Fe} 1, \mathrm{Fe} 2$, and $\mathrm{S} 2$ ) and sulfur oxidation, and the effect of $\mathrm{pH}$ on the oxidation. As shown in Fig. 3a, strains of sulfur-oxidizing bacteria had very high sulfur oxidation activities in the range of $\mathrm{pH} \mathrm{1-6}$ and an optimum $\mathrm{pH}$ of 3-5. The media $\mathrm{pH}$ decreased finally to $0.5-0.7$ because of active sulfur oxidation by the sulfur-oxidizing thiobacilli. Strain Fel and also T. ferrooxidans NCIB 8455 showed relatively high sulfur-oxidizing activity with an optimum at $\mathrm{pH} 4-5$. With the iron-oxidizing thiobacilli, the media $\mathrm{pH}$ also decreased finally to about 0.5 due to prolonged sulfur oxidation. The values of $\mu$ were 0.08 (Fe1), 0.07 ( $T$. ferrooxidans NCIB 8455), 0.09 (S2), and 0.07 (S3). However, the sulfur-oxidizing activity of strain $\mathrm{Fe} 2$ was extremely low. Only feeble sulfur oxidation occurred in the range of pH 4-6 after 7 days cultivation with a large inoculum $\left(4 \times 10^{9} / \mathrm{ml}\right)$ (Fig. 3a). A very small increase of sulfate $(300 \mathrm{mg} / l)$ was produced by $\mathrm{Fe} 2$, with no detectable increase in bacterial numbers even after 12 days of incubation (Fig. 3b). And adding a trace metal solution $\left(\mathrm{Zn}^{2+}, \mathrm{Mn}^{2+}, \mathrm{Cu}^{2+}, \mathrm{Co}^{2+}, \mathrm{B}^{3+}\right.$, or $\left.\mathrm{Mo}^{6+}\right)$ and surface active agent (Tween 80 ) did no increase the sulfur oxidation. 

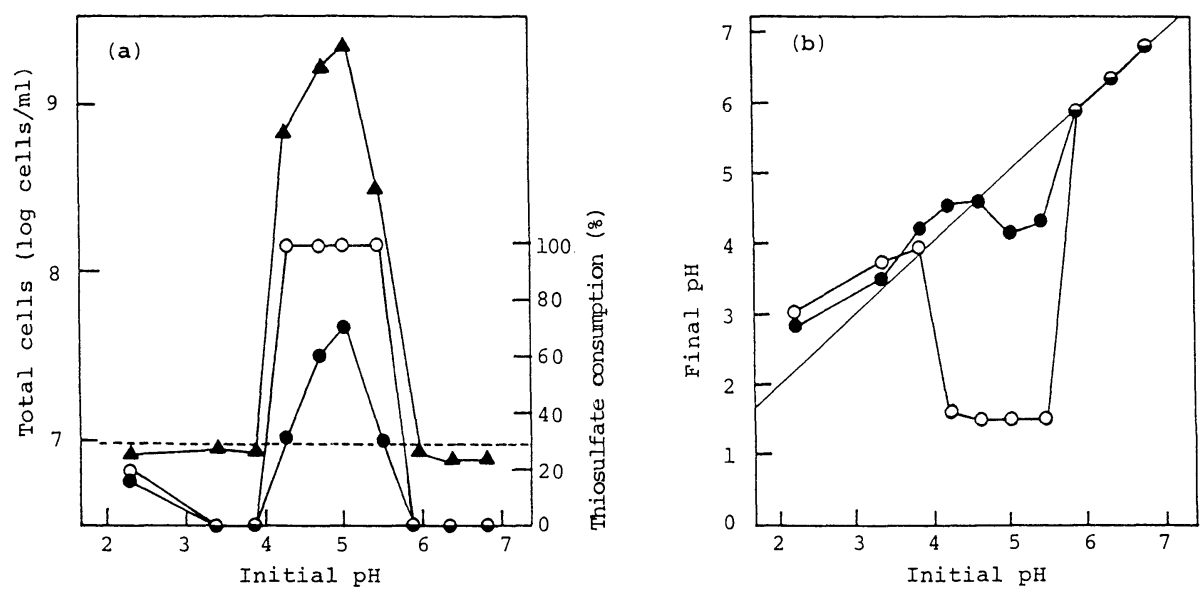

Fig. 4. Effects of $\mathrm{pH}$ on growth of sulfur-oxidizing bacteria (S2) and oxidation of thiosulfate.

(a): $\mathrm{Na}_{2} \mathrm{~S}_{2} \mathrm{O}_{3}-9 \mathrm{~K}$ media adjusted to $\mathrm{pH} 2.3-6.8$ were used. Inoculum size: $1 \times 10^{7} / \mathrm{ml}$. $\Delta$ : cell number (2-day culture), $\bullet$ : thiosulfate (2-day culture), $\bigcirc$ : thiosulfate (3-day culture).

(b): The same experiment as in (a). ๑: 2-day culture, $\bigcirc$ : 3-day culture.

\section{Oxidation of thiosulfate}

Strains S2 and S3 of sulfur-oxidizing bacteria oxidized much thiosulfate but not iron. The $\mathrm{pH}$ ranges for their apparent thiosulfate oxidation was 4.3-5.5. The optimum was $\mathrm{pH} 4.8-5.0$ (Fig. 4). Strains of iron-oxidizing bacteria (Fe1 and $T$. ferrooxidans NCIB 8455) also had high thiosulfate-oxidizing activities in the $\mathrm{pH}$ range of 4.2-5.6 and the optimum $\mathrm{pH}$ was 4.6-5.0 (Fig. 5). The values of $\mu$ were 0.06 (S2), 0.05 (S3), 0.05 (Fe1), and 0.04 ( $T$. ferrooxidans NCIB 8455). As shown in Figs. 4 and 5 , the $\mathrm{pH}$ values and thiosulfate consumption of the media tended to increase gradually in the acid $\mathrm{pH}$ ranges when the thiosulfate was not oxidized, suggesting chemical decomposition of the substrate in the acid condition.

There was a difference in the thiosulfate oxidation between the sulfur- and iron-oxidizing bacteria (Fig. 6). In the sulfur-oxidizing bacteria, both the bacterial growth and $\mathrm{pH}$ decrease (sulfate increase) stopped just when thiosulfate was completely consumed. But, with iron-oxidizing bacteria, the cell numbers increased along with a $\mathrm{pH}$ decrease (sulfate increase) even after complete absence of the substrate. This shows the differences in the thiosulfate-metabolizing system of iron- and sulfur-oxidizing bacteria.

As shown in Fig. 7, the thiosulfate oxidation by strain Fe2 was extremely low. But the oxidation by strain Fel was very fast with only a small inoculum $\left(1 \times 10^{7} / \mathrm{ml}\right)$ (Fig. 5). However, with a large bacterial inocula (ca. $10^{9} / \mathrm{ml}$ ), very weak and unstable oxidation of the substrate occurred after a prolonged incubation (Fig. 7b). 

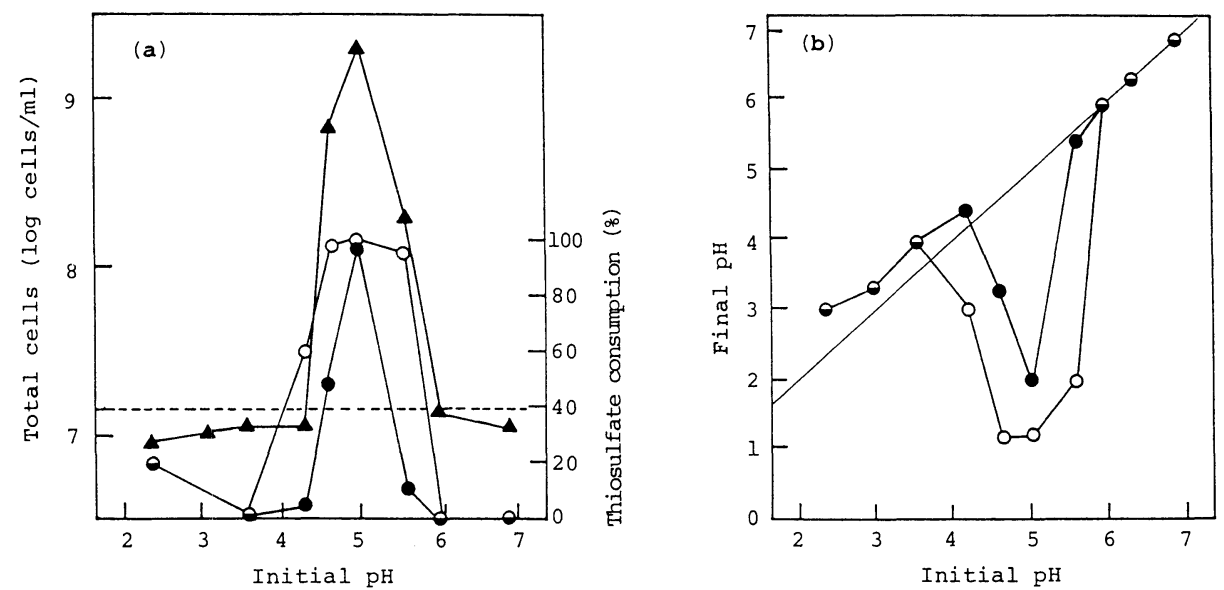

Fig. 5. Effects of $\mathrm{pH}$ on growth of iron-oxidizing bacteria $(\mathrm{Fe} 1)$ and oxidation of thiosulfate.

(a): $\mathrm{Na}_{2} \mathrm{~S}_{2} \mathrm{O}_{3}-9 \mathrm{~K}$ media adjusted to $\mathrm{pH} 2.3-6.8$ were used. Inoculum size: $1 \times 10^{7} / \mathrm{ml}$. $\Delta$ : cell number (3-day culture), $\bullet$ : thiosulfate (3-day culture), $\bigcirc$ : thiosulfate (5-day culture). (b): The same experiment as in (a). ๑: 3-day culture, $\bigcirc$ : 5-day culture.

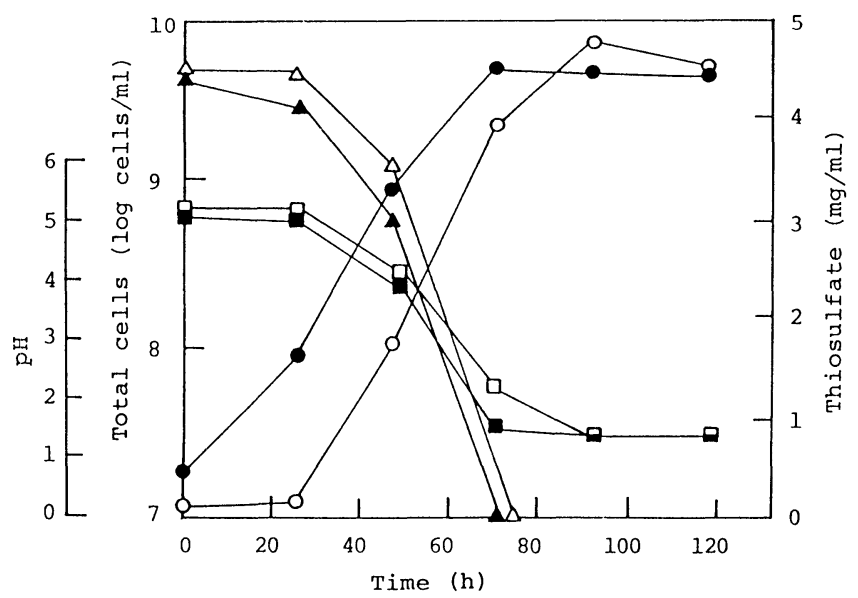

Fig. 6. Progressive changes in growth of iron- and sulfur-oxidizing bacteria (Fel and S2) on thiosulfate and its oxidation.

$\mathrm{Na}_{2} \mathrm{~S}_{2} \mathrm{O}_{3}-9 \mathrm{~K}$ medium (pH 5) was used. S2: •, cell number; $\boldsymbol{\Delta}$, thiosulfate; $\boldsymbol{\square}, \mathrm{pH}$.

Fel: $\bigcirc$, cell number; $\triangle$, thiosulfate; $\square, \mathrm{pH}$.

\section{Glucose utilization}

To determine whether the strains of iron-oxidizing bacteria (Fe1, $\mathrm{Fe} 2$, and $T$. ferrooxidans NCIB 8455) grow heterotrophically, these bacteria, after a brief previous adaptation to glucose in $\mathrm{FeSO}_{4}-9 \mathrm{~K}$ medium, were cultivated in $9 \mathrm{~K}$ salts 

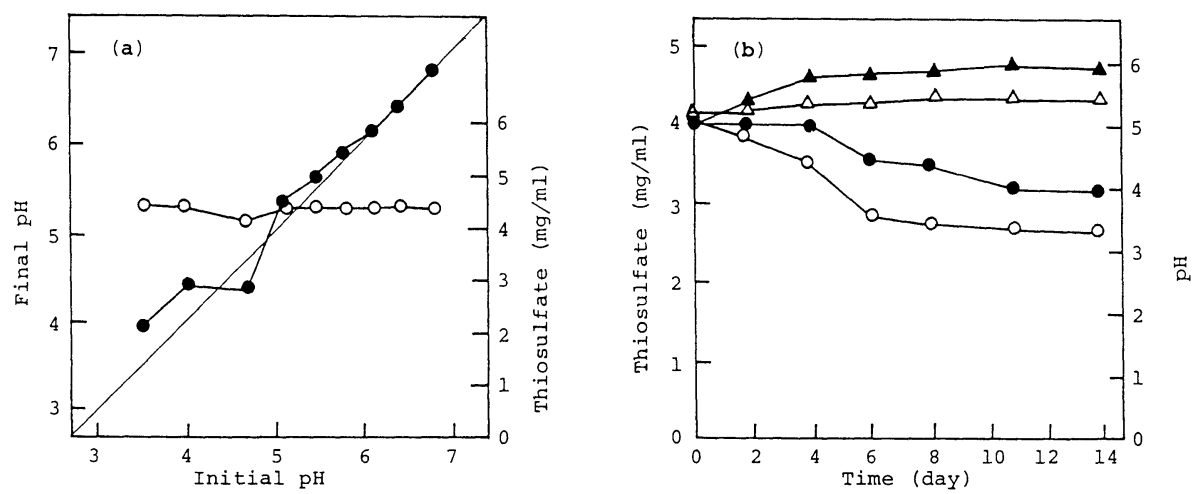

Fig. 7. Effects of $\mathrm{pH}$ on the oxidation of thiosulfate by iron-oxidizing bacteria $(\mathrm{Fe} 2)$ and progressive changes in its oxidation.

(a): $\mathrm{Na}_{2} \mathrm{~S}_{2} \mathrm{O}_{3}-9 \mathrm{~K}$ media adjusted to $\mathrm{pH} 3.5-6.8$ were used and cultivated for 10 days. Inoculum size: $1 \times 10^{9} / \mathrm{ml}$. $\bullet$ : $\mathrm{pH}$, ○: thiosulfate. (b) Inoculum size: $4 \times 10^{9} / \mathrm{ml}$. $\bullet$ and $\boldsymbol{\Delta}$ : $\mathrm{pH}, \bigcirc$ and $\triangle$ : thiosulfate. Data of replicate flasks were given here.

Table 1. Utilization of glucose by the strains of iron-oxidizing bacteria.

\begin{tabular}{|c|c|c|c|c|}
\hline \multirow{2}{*}{ Strain } & \multicolumn{2}{|c|}{ Glucose $(\mathrm{mg} / \mathrm{ml})^{a}$} & \multicolumn{2}{|c|}{ Bacterial no. $(\text { cells } / \mathrm{ml})^{a}$} \\
\hline & 0 & $72(\mathrm{~h})$ & 0 & $72(h)$ \\
\hline $\mathrm{Fel}$ & 10.5 & 10.0 & $2.5 \times 10^{7}$ & $2.3 \times 10^{7}$ \\
\hline $\mathrm{Fe} 2$ & 10.5 & 10.7 & $2.5 \times 10^{7}$ & $2.4 \times 10^{7}$ \\
\hline $\begin{array}{l}\text { T. ferrooxidans } \\
\text { (NCIB 8455) }\end{array}$ & 10.6 & 10.3 & $1.6 \times 10^{7}$ & $1.3 \times 10^{7}$ \\
\hline
\end{tabular}

a Data indicate glucose concentrations and bacterial numbers at start and after $72 \mathrm{~h}$ incubation.

medium with $1 \%(\mathrm{w} / \mathrm{v})$ glucose. As shown in Table 1, none of the strains grew on glucose, indicating their obligate chemolithotrophy.

\section{Chemotaxonomical characteristics}

As shown in Table 2 with some published data, all the strains ( $\mathrm{Fe} 1, \mathrm{Fe} 2, \mathrm{~S} 2$, and S3) of iron- and sulfur-oxidizing bacteria contained ubiquinone Q-8 as a major component. The DNA G+C contents of strains Fe1 and Fe2 were $56-57 \mathrm{~mol} \%$, whereas those of the strains S2 and S3 were 51-52 mol\%. Strains Fe1 and Fe2 had $\mathrm{C} 16: 0, \mathrm{C} 16: 1$, and $\mathrm{C} 18:: 1$ as major non-hydroxylated fatty acids. Strains S2 and $\mathrm{S} 3$ had C12:0, C16:1, C18:1, and C19cyc as major non-hydroxylated fatty acids. All the strains had 3-OH $\mathrm{C} 14: 0$ as hydroxy fatty acids. The cellular fatty acid composition of strains Fe1 (Fe2) and S2 (S3) were almost the same as those of the type strains of $T$. ferrooxidans and $T$. thiooxidans, respectively. 


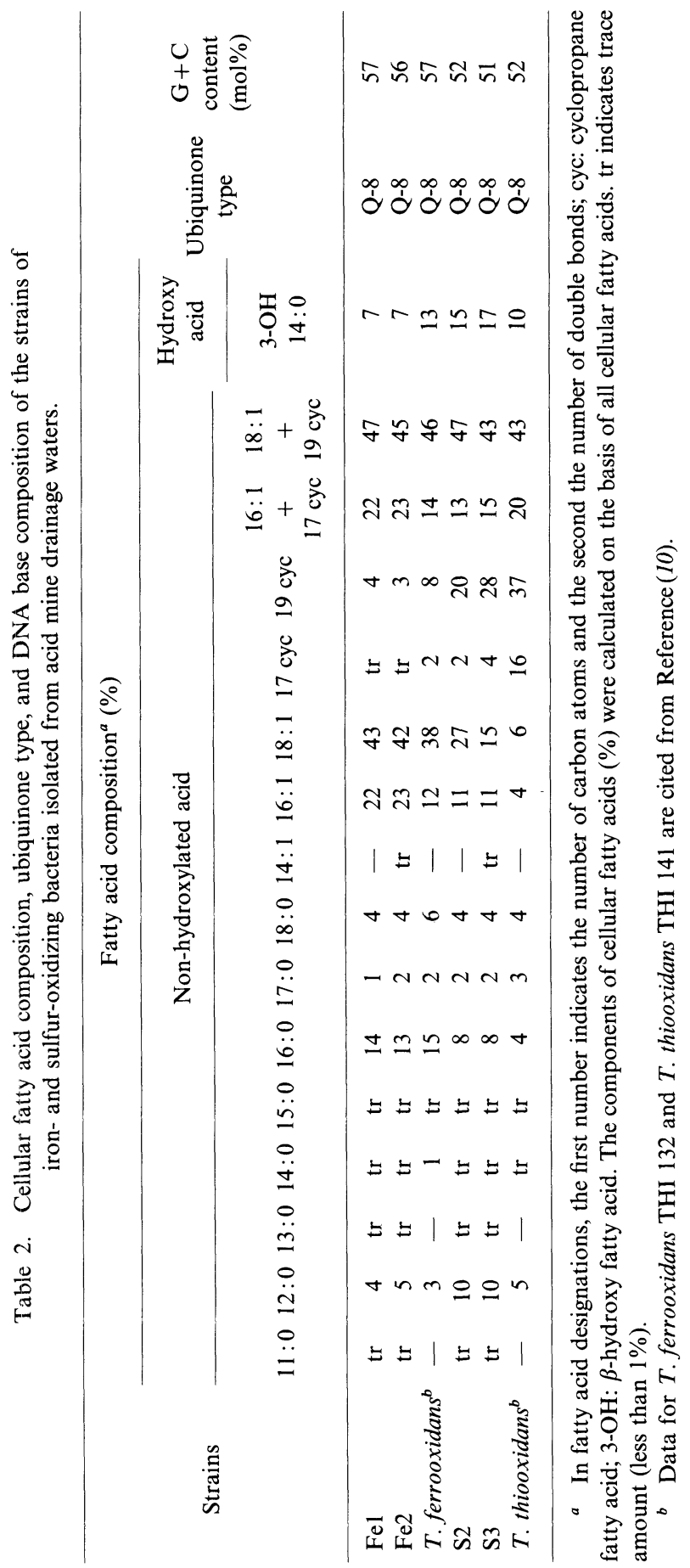




\section{DISCUSSION}

All the strains ( $\mathrm{Fe} 1, \mathrm{Fe} 2, \mathrm{~S} 2$, and $\mathrm{S} 3$ ) isolated from the Matsuo mine were obligately autotrophic, aerobic, acidophilic, gram negative, non-spore forming, and rod shaped. Strains S2 and S3 are quite similar in properties and were identified as $T$. thiooxidans. Strains $\mathrm{Fe} 1$ and $\mathrm{Fe} 2$ belong to $T$. ferrooxidans. $\mathrm{Fe} 1$ has often been used in our studies (25-27). However, strains Fe1 and Fe2 are different in their ability to oxidize sulfur and thiosulfate. Strain $\mathrm{Fe} 2$ oxidizes the substrates very weakly. It is fortuitous that the two strains Fe1 and Fe2 may be different among the strains of $T$. ferrooxidans. The phenotypical characteristics of $T$. ferrooxidans or $T$. thiooxidans are too few to classify and identify the groups of numerous bacterial strains solely by them. A. P. Harrison (8) studied the genomic and physiological diversity among 23 strains of $T$. ferrooxidans, and showed that the strains have a wide range of $\mathrm{G}+\mathrm{C}$ content $(53-65 \mathrm{~mol} \%)$ and diverge into 7 different DNA homology groups. His study demonstrates genetic differences at the strain level of $T$. ferrooxidans and $T$. thiooxidans, and also indicates the importance of studying systematically the genetic and physiological characteristics of a large collection of strains isolated from various habitats.

It was difficult to determine exactly the ratios of $\mathrm{Fe} 1$ and $\mathrm{Fe} 2$ colonies developed on ferrous iron solid medium, but the Fel colonies were rather dominant in acid mine drainage waters. It is significant that different strains of iron-oxidizing bacteria are coexistent in the same water sample. Between the two kinds of colonies (S1 and S2) developed on thiosulfate silica gel medium, S2 was easily isolated and identified as a typical strain of $T$. thiooxidans, but $\mathrm{S} 1$ did not grow in pure cultures with either sulfur, thiosulfate, or iron as a sole energy source. This signifies the importance of the coexistence of S1 with S2 for the growth of S1 or the presence of unknown growth factors. The counts of S1 and S2 were almost equal, $10^{2} / \mathrm{ml}$ in acid mine waters and $10^{6} / \mathrm{g}$ in pyrite ores. Considering the presence of a large number of $\mathrm{S} 1$ in the mine areas, it is worthwhile to try to isolate $\mathrm{S} 1$ and investigate its characteristics.

As indicated in Figs. 4 and 5, the thiobacilli commence to grow on thiosulfate only in the range of $\mathrm{pH} 4.2$ to 5.6 but in sulfur-containing medium the $\mathrm{pH}$ range extends widely from 1 to 6 . These results are supported by the findings of previous workers $(2,9)$. Tuovinen and Kelly $(20)$ reported also the narrow starting $\mathrm{pH}$ range ( $\mathrm{pH} 3.6-4.7$ ) for growth on thiosulfate, which is smaller by about one $\mathrm{pH}$ unit than the present results.

It is noteworthy that distinct differences in the $\mathrm{pH}$ ranges for the oxidation of thiosulfate, sulfur, and ferrous iron by the acidophilic thiobacilli are related to the stability of the substrates for energy in the acid $\mathrm{pH}$ range. Sulfur is extremely stable chemically and can be utilized as an energy source over a wide acid $\mathrm{pH}$ range $(\mathrm{pH}$ 1-6). Ferrous iron, serving as a favorite substrate for iron-oxidizing bacteria, is stable and almost not auto-oxidizable in strong acid conditions below $\mathrm{pH}$ 4.0. But the favorite $\mathrm{pH}$ for thiosulfate oxidation by the thiobacilli living below $\mathrm{pH}$ ca. 
6 are in more limited and milder acid conditions ( $\mathrm{pH} \mathrm{4.2-5.6)} \mathrm{than} \mathrm{that} \mathrm{for} \mathrm{iron}$ oxidation, possibly because thiosulfate is unstable and spontaneously decomposable in the acid conditions below pH 4.

Iron- and sulfur-oxidizing thiobacilli fail to grow on thiosulfate in acid condition below $\mathrm{pH}$ 4.2. The fate of thiosulfate in those acid conditions is complicated and obscure, but there is evidence that tetrathionate, trithionate, and related compounds (sulfur, sulfide, sulfite, bisulfite, various polythionic acids) are formed during thiosulfate oxidation by the thiobacilli $(15,16,20)$. It is possible that thiosulfate and its related products in solution at $\mathrm{pH} 4.2$ and below, probably including $\mathrm{HS}_{2} \mathrm{O}_{3}^{1-}$ and $\mathrm{SO}_{3}^{2-}$, inhibit either thiosulfate uptake or metabolism by the thiobacilli (20).

Strains Fe1, Fe2, S2, and S3 have been given laboratory strain names, AIU 001, 002, 101, and 102, respectively, and also have been deposited in the Japan Collection of Microorganisms, Institute of Physical and Chemical Research, as strains JCM 7811, 7812, 7813, and 7814, respectively.

\section{REFERENCES}

1) Colmer, A. R. and Hinkle, M. E., The role of microorganisms in acid mine drainage: a preliminary report. Science, 106, 253-256 (1947).

2) Colmer, A. R., Relation of the iron oxidizer, Thiobacillus ferrooxidans, to thiosulfate. J. Bacteriol., 83, 761-765 (1962).

3) De Ley, J., Re-examination of the association between melting point, buoyant density and chemical composition of deoxyribonucleic acid. J. Bacteriol., 101, 738-754 (1970).

4) Dodgson, K. S., Determination of inorganic sulphate in studies on the enzymic and non-enzymic hydolysis of carbohydrate and other sulphate esters. Biochem. J., 78, 312-319 (1961).

5) Dubois, M., Gilles, K. A., Hamilton, J. K., Rebers, P. A., and Smith, F., Colorimetric method for the determination of sugars and related substrates. Anal. Chem., 28, 350-356 (1956).

6) Hanya, T., In Methods for Examination of Water Quality, Maruzen Co., Tokyo (1960), p.253-256.

7) Harrigan, W. F. and McCance, M. F., In Laboratory Methods in Microbiology, Academic Press, New York (1966), p. 8.

8) Harrison, Jr., A. P., Genomic and physiological diversity amongst strains of Thiobacillus ferrooxidans. Arch. Microbiol., 131, 68-76 (1982).

9) Hutchinson, M., Johnston, K. I., and White, D., Taxonomy of the acidophilic thiobacilli. J. Gen. Microbiol., 44, 373-381 (1966).

10) Katayama-Fujimura, Y., Tsuzaki, N., and Kuraishi, H., Ubiquinone, fatty acid and DNA base composition determination as a guide to the taxonomy of the genus Thiobacillus. J. Gen. Microbiol., 128, 1599-1611 (1982).

11) Kelly, D. P. and Harrison, A. P., In Bergey's Manual of Systematic Bacteriology, Vol. 3, Williams and Wilkins Co., Baltimore (1984), p. 1842-1858.

12) Marmur, J., A procedure for the isolation of deoxyribonucleic acid from micro-organisms. J. Mol. Biol., 3, 208-218 (1961).

13) Marmur, J. and Doty, P., Determination of the base composition of DNA from its thermal denaturation temperature. J. Mol. Biol., 5, 109-118 (1962).

14) Miyagawa, E., Azuma, R., and Suto, T., Cellular fatty acid composition in gram-negative obligately anaerobic rods. J. Gen. Appl. Microbiol., 25, 41-51 (1979).

15) Parker, C. D. and Prisk, J., The oxidation of inorganic compounds of sulphur by various sulphur bacteria. J. Gen. Microbiol., 8, 344-364 (1953). 
16) Roy, A. B. and Trudinger, P. A., In The biochemistry of inorganic compounds of sulphur, Cambridge University Press, London (1970), p. 207.

17) Shafia, F. and Wilkinson, R. F., Growth of Ferrobacillus ferrooxidans on organic matter. $J$. Bacteriol., 97, 256-260 (1969).

18) Silvermann, M. P. and Lundgren, D. G., Studies on the chemoautotrophic iron bacterium Ferrobacillus ferrooxidans. I. An improved medium and a harvesting procedure for securing high cell yields. J. Bacteriol., 77, 642-647 (1959).

19) Takagi, S., In Quantitative Analysis (Experiments and Calculations) II: Volumetric Analysis, Kyoritsu Publishing Co., Tokyo (1976), p.419-464.

20) Tuovinen, O. H. and Kelly, D. P., Studies on the growth of Thiobacillus ferrooxidans. V. Factors affecting growth in liquid culture and development of colonies on solid media containing inorganic sulphur compounds. Arch. Microbiol., 98, 351-364 (1974).

21) Wakao, N., Sakurai, Y., and Shiota, H., Microbial oxidation of ferrous iron in acid mine water at sulfur and iron-sulfide mine. Soil Sci. Plant Nutr., 23, 207-216 (1978).

22) Wakao, N., Hanada, K., Sakurai Y., and Shiota, H., Seasonal variations in number of acidophilic iron-oxidizing bacteria and iron oxidation in the river contaminated with acid mine water. Soil Sci. Plant Nutr., 24, 491-501 (1978).

23) Wakao, N., Yoshida, M., Sakurai, Y., and Shiota, H., Microbial iron oxidation and color change of lake Matsuo-Goshikinuma having a character of continuous culture system. J. Fac. Agric., Iwate Univ., 15, 29-47 (1980).

24) Wakao, N., Hanada, K., Sakurai, Y., and Shiota, H., Distribution of acidophilic iron- and sulfur-oxidizing bacteria in a sulphur and iron-sulphide mine. Soil Sci. Plant Nutr., 27, 505-510 (1981)

25) Wakao, N., Mishina, M., Sakurai, Y., and Shiota, H., Bacterial pyrite oxidation I. The effect of pure and mixed cultures of Thiobacillus ferrooxidans and Thiobacillus thiooxidans on release of iron. J. Gen. Appl. Microbiol., 28, 331-343 (1982).

26) Wakao, N., Mishina, M., Sakurai Y., and Shiota, H., Bacterial pyrite oxidation II. The effect of various organic substances on release of iron from pyrite by Thiobacillus ferrooxidans. J. Gen. Appl. Microbiol., 29, 177-185 (1983).

27) Wakao, N., Mishina, M., Sakurai Y., and Shiota, H., Bacterial pyrite oxidation III. Adsorption of Thiobacillus ferrooxidans cells on solid surfaces and its effect on iron release from pyrite. $J$. Gen. Appl. Microbiol., 30, 63-77 (1984).

28) Waksman, S. A. and Joffe, J. S., Acid production by a new sulfur oxidizing bacterium. Science, 53, $216(1921)$ 